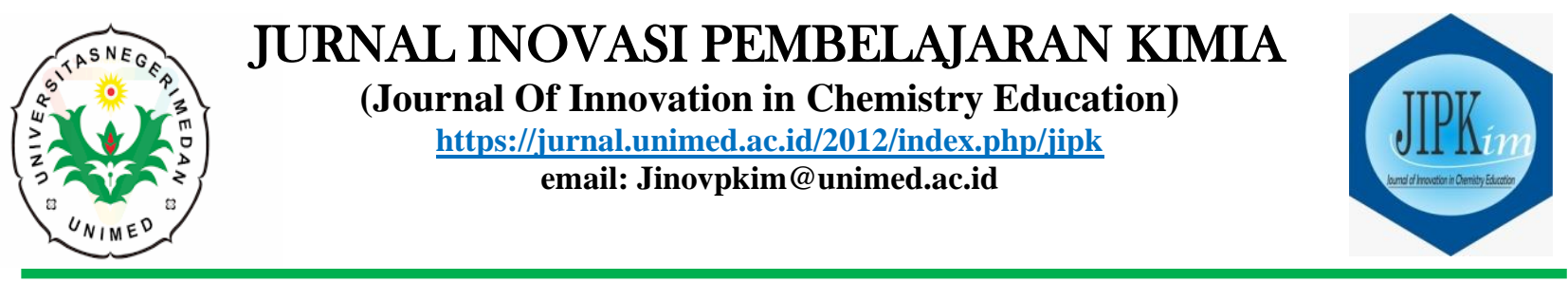

\title{
ANALISIS PBL DENGAN DL MENGGUNAKAN MACROMEDIA FLASH TERHADAP MOTIVASI DAN HASIL BELAJAR SISWA PADA MATERI LAJU REAKSI DI SMA NEGERI 10 MEDAN
}

\author{
Siska Lestari Siregar ${ }^{\mathrm{a}, *}$, Freddy Tua Musa Panggabean ${ }^{\mathrm{a}}$ \\ ${ }^{a}$ Program Studi Pendidikan Kimia, Universitas Negeri Medan, Medan \\ *Alamat Korespondensi: siregarsiska21@gmail.com
}

\begin{abstract}
:
The study aims (1) To find out whether there are differences in the value of student learning outcomes taught by PBL and DL models using macromedia flash (2) To find out the significant correlation between motivation and student learning outcomes. From the data analysis: (1) Student learning outcomes $(84.06 \pm 7.771)$ taught by applying PBL model using macromedia flash and student learning outcomes $(74.53 \pm 6.395)$ taught by applying $D L$ model using macromedia flash which obtained a t-test of 5.357 and a sig value of 0,000<0.05 (2) the correlation between student learning outcomes and student motivation in experimental class I obtained a correlation price of 0.955 while sig. (2-tailed) is 0,000 this value is smaller than the critical limit $\alpha=0.05(0,000<0.05)$, meaning there is a very significant relationship between the two variables in the experimental class-I. And the correlation between learning outcomes and student motivation in experimental class II obtained a correlation value of 0.930 while sig. $(2$-tailed) is 0,000 this value is smaller than the critical limit $\alpha=0.05(0.000<0.05)$, means that

there is a very significant relationship between the two variables in the experimental class-II.
\end{abstract} Keywords:

Problem Based Learning, Discovery Learning, Macromedia Flash, Learning Outcomes, Learning Motivation

\section{PENDAHULUAN}

Masalah utama dalam proses pembelajaran adalah masih rendahnya daya serap peserta didik. Proses pembelajaran kebanyakan masih berpusat kepada guru (teacher centered) sehingga guru tidak memberikan ruang akses bagi siswa untuk berkembang secara mandiri (Trianto, 2011). Hasil observasi nilai KKM di kelas XI SMA N-10 Medan yaitu 70 untuk mata pelajaran kimia materi laju reaksi, sementara persentase nilai kelulusannya memiliki nilai rata-rata sebesar 65 .

Menurut Abidin (2014), siswa terbiasa dengan informasi yang diperoleh dari guru sebagai narasumber utama, sehingga siswa merasa kurang nyaman dengan cara belajar sendiri dalam proses pemecahan masalah. Widaningsih (2019), menyatakan bahwa problem based learning (PBL) merupakan pembelajaran berbasis masalah dan peserta didik dapat belajar tentang subjek melalui pengalaman .

Utami dkk., (2018), menyatakan bahwa penerapan model PBL pada hasil belajar kognitif siswa di kelas eksperimen sebesar 40,00 dan kelas kontrol sebesar 30,00. Menurut Ikman \& Monovatra (2016), berdasarkan hasil data N-Gain dengan penerapan PBL dan hasil pretest kelas eksperimen 35,9 dan post test 76,2, kelas kontrol pretest 33,3 dan post test 54,2. 
Martaida dkk., (2017), menyatakan bahwa terdapat serangkaian kegiatan belajar yang menekankan pada proses berfikir kritis dan mencari tahu sendiri jawabannya untuk masalah yang diajukan. Inti dari pembelajaran ini yaitu untuk memberi siswa masalah dengan menghadapi dunia nyata yang disebut sebagai model pembelajaran discovery leaarning (DL). Kurniasih dkk., (2014), menyatakan bahwa model DL merupakan suatu teori belajar yang didefinisikan sebagai proses pembelajaran yang terjadi apabila siswa tidak disajikan dengan pelajaran dalam bentuk finalnya, tetapi diharapkan mengorganisasi sendiri.

Menurut Akhsanul (2017), bahwa penerapan model DL pada hasil belajar siswa dengan nilai rata-rata 96 dan hasil belajar individu 95. Menurut Sugiarti dkk., (2018), bahwa penerapan model DL pada perbedaan sikap ilmiah peserta didik kelas eksperimen I dengan nilai rata-rata sebesar 74,57 dan kelas eksperimen II sebesar 64,26. Menurut Luthfi dkk., (2016), bahwa penerapan model DL pada hasil analisis deskriptif menunjukkan nilai post test kelas eksperimen I lebih tinggi dari kelas eksperimen II $(73,80>67,71)$. Menurut Suyati \& Sutiani (2018), bahwa penerapan model DL pada hasil belajar siswa pada siklus I nilai rata-rata sebesar 83,38 dengan nilai terendah sebesar 71 dan nilai tertinggi sebesar 89.

Gusbandono dkk., (2013), pada penggunaan media yang inovatif dan sesuai dengan tujuan pembelajaran, materi dan keadaan siswa serta sarana yang tersedia juga dapat mendukung terciptanya pembelajaran yang menarik. Menurut Walisda dkk., (2015), macromedia flash adalah salah satu perangkat lunak yang mampu membuat media pembelajaran dalam bentuk audio visual. Metode pembelajaran animasi macromedia flash menggunakan sistem pembelajaran perangkat lunak dan perangkat keras yang dapat menyederhanakan proses data dalam bentuk gambar, video, fotografi, grafik, dan animasi, bekerjasama dengan suara, teks, dan suara data yang dikendalikan interaktif oleh komputer.
Menurut Sinar (2018), bahwa hasil belajar merupakan prestasi yang dicapai setelah siswa selesai melakukan materi pembelajaran dan hasil belajar juga merupakan suatu hasil dari penugasan ilmu pengetahuan dalam bentuk perilaku yang harus dicapai oleh siswa selama belajar di sekolah. Badaruddin (2015), menyatakan salah satu faktor internal yang juga memengaruhi hasil belajar siswa yaitu motivasi dalam belajar. Setiap siswa mempunyai motivasi tersendiri baik yang timbul dari dalam diri sendiri maupun melalui faktor luar yang berbeda-beda tergantung bagaimana seorang siswa dapat mengolah, menerima, dan mengatur informasi yang diterimanya.

Penelitian ini bertujuan untuk mengetahui: (1) Apakah terdapat perbedaan nilai hasil belajar siswa yang dibelajarkan dengan model PBL dan DL menggunakan macromedia flash; (2) Korelasi yang signifikan antara motivasi dengan hasil belajar siswa.

\section{METODE}

Penelitian ini dilaksanakan di SMA Negeri 10 Medan, Jalan Tilak No. 108, Sei Rengas I, Medan, Sumatera Utara, Semester Ganjil, T.A. 2019/2020.

Penelitian dilaksanakan selama 6 bulan dalam interval waktu ini, sudah termasuk kegiatan survei pendahuluan, pengurusan proposal penelitian, uji coba instrument, pengumpulan data, analisis data dan penulisan laporan akhir penelitian.

Populasi penelitian ini adalah seluruh siswa kelas XI SMA Negeri 10 Medan sebanyak 3 kelas. Dalam penelitian ini sampelnya diambil secara random sebanyak dua kelas, yaitu kelas XI MIA 1 terdiri 32 siswa dan XI MIA 2 terdiri 32 siswa. Untuk memeroleh data pada penelitian ini digunakan instrumen non tes berupa angket motivasi dan instrumen tes berupa soal pilihan ganda sebanyak 20 Soal.

Penelitian ini menggunakan teknik analisis uji t-dua pihak dan uji korelasi dengan bantuan SPSS 20. Pada kelas eksperimen I diajarkan dengan menerapkan 
model PBL dengan media macromedia flash dan pada kelas eksperimen II diajarkan dengan menerapkan model DL dengan media macromedia flash.

Metode yang digunakan adalah metode eksperimental dengan desain OneGroup Pre-test-Posttest Design. Setelah diperoleh data hasil penelitian maka dilakukan Uji Normalitas data menggunakan Uji Liliefors dengan kriteria jika Lhitung < Ltabel maka data berdistribusi normal. Kemudian, Uji Homogenitas dengan menggunakan Uji $\mathrm{F}$ atau uji kesamaan varians dengan kriteria jika $F_{\text {tabel }}<F_{\text {hitung }}$ maka data memiliki varians yang homogen.

Setelah itu dilakukan uji hipotesis dengan menggunakan Uji t-dua pihak (Independent-Samples $T$ Test) dan Uji Korelasi (Correlate Bivariate) dengan bantuan SPSS 20, dan dari hasil uji hipotesis tersebut maka peneliti dapat menarik kesimpulan.

\section{HASIL DAN PEMBAHASAN}

Berdasarkan hasil penelitian yang dilakukan dengan penerapan model PBL dan DL menggunakan media macromedia flash, secara ringkas diperlihatkan pada tabel berikut.

Tabel 1. Descriptive Statistik Kelas Eksperimen-I

\begin{tabular}{lccccccc}
\hline & N & Min & Max & Sum & Mean & $\begin{array}{c}\text { Std. } \\
\text { Deviation }\end{array}$ & Variance \\
\hline Pretes Eks-I & 32 & 20 & 55 & 1160 & 36,250 & 8,707 & 75,806 \\
Postes Eks-I & 32 & 70 & 95 & 2690 & 84,06 & 7,771 & 60,383 \\
Motivasi & 32 & 35 & 194 & 4592 & 143,50 & 45,008 & 2025,742 \\
Belajar & & & & & & & \\
\hline
\end{tabular}

Berdasarkan tabel 1 diatas diperoleh nilai rata-rata pretes sebesar 36,250 , nilai nilai rata-rata postest sebesar 84,06 , dan nilai rata-rata motivasi belajar sebesar 143,50.

Tabel 2. Descriptive Statistik Kelas Eksperimen-II

\begin{tabular}{lccccccc}
\hline & N & Min & Max & Sum & $\begin{array}{c}\text { Mea } \\
\text { N }\end{array}$ & $\begin{array}{c}\text { Std. } \\
\text { Deviat } \\
\text { Ion }\end{array}$ \\
\hline Pretes Eks - II & 32 & 15 & 55 & 1120 & 35,00 & 9,588 & 91,935 \\
Postes Eks - II & 32 & 65 & 85 & 2385 & 74,53 & 6,395 & 40,902 \\
$\begin{array}{l}\text { Motivasi } \\
\text { Belajar }\end{array}$ & 32 & 35 & 194 & 4496140,50 & 49,047 & 2405,613 \\
\hline
\end{tabular}

Berdasarkan tabel 2 diatas diperoleh nilai rata-rata pretes sebesar 35,00 , nilai postes sebesar 74,53 , nilai motivasi belajar sebesar 140,50. Pada kolom mean terdapat perbedaan hasil belajar siswa kelas eksperimen I $(84,06 \pm 7,771)$ yang diajarkan dengan menerapkan model PBL menggunakan media macromedia flash dan hasil belajar siswa kelas eksperimen II $(74,53 \pm 6,395)$ yang diajarkan dengan menerapkan model DL menggunakan media macromedia flash.

Tabel 3. Analisis Data Hipotesis Pertama

\begin{tabular}{|c|c|c|c|c|c|}
\hline \multirow{2}{*}{ Analisis } & \multicolumn{2}{|c|}{ Data Kelas } & \multirow{2}{*}{ Thit } & \multirow{2}{*}{ Ttabel } & \multirow{2}{*}{ Kes } \\
\hline & Eks- I & Eks- II & & & \\
\hline Manual & $\begin{array}{c}\bar{x}=84,06 \\
\mathrm{~S}=7,77\end{array}$ & $\begin{array}{c}\bar{x}=74,53 \\
\mathrm{~S}=6,39\end{array}$ & 5,35 & 1,98 & $\begin{array}{c}\mathrm{Ha} \\
\text { diterima }\end{array}$ \\
\hline SPSS 20 & $\begin{array}{c}\bar{x}=84,06 \\
\mathrm{~S}=7,77\end{array}$ & $\begin{array}{c}\bar{x}=74,53 \\
\mathrm{~S}=6,39\end{array}$ & 5,35 & 0,00 & $\begin{array}{c}\mathrm{Ha} \\
\text { diterima }\end{array}$ \\
\hline
\end{tabular}

Pada tabel diatas diperoleh uji $\mathrm{t}$ sebesar 5,35 dan nilai sig. 0,00. Karena nilai sig. < 0,05 maka $\mathrm{H}_{\mathrm{a}}$ diterima atau $\mathrm{H}_{\mathrm{o}}$ ditolak yang berarti hipotesis pertama diterima dan teruji kebenarannya pada taraf $\alpha=0,05$ sehingga dapat disimpulkan bahwa terdapat perbedaan nilai hasil belajar siswa yang diberi pengajaran problem based learning (PBL) dan discovery learning (DL) menggunakan media macromedia flash.

Tabel 4. Analisis Data Hipotesis Kedua

\begin{tabular}{ccccccc}
\hline \multirow{2}{*}{ No } & \multirow{2}{*}{ Kelas } & \multicolumn{2}{c}{ Manual } & \multicolumn{2}{c}{ SPSS } & \multirow{2}{*}{ Kes } \\
\cline { 3 - 6 } & & Rhit & rtabel & Rhit & Sig & \\
1. & Eks- I & 0,955 & 0,349 & 0,955 & 0,000 & Ha diterima \\
2. & Eks- II & 0,930 & 0,349 & 0,930 & 0,000 & Ha diterima \\
\hline
\end{tabular}

Pada kolom kelas eksperimen-I diperoleh $\mathrm{r}$ hit sebesar 0,955 dan nilai sig. 0,000. Karena nilai sig. $<0,05$, maka Ha diterima atau Ho ditolak yang berarti hipotesis kedua diterima dan teruji kebenarannya pada taraf $\alpha=0,05$ sehingga dapat disimpulkan bahwa terdapat korelasi antara motivasi belajar dengan hasil belajar siswa pada kelas eksperimen I.

Pada kolom kelas eksperimen-II diperoleh $\mathrm{r}$ hit sebesar 0,930 dan nilai sig. 0,000. Karena nilai sig. $<0,05$ maka $\mathrm{Ha}_{\mathrm{a}}$ diterima atau $\mathrm{H}_{\mathrm{o}}$ ditolak yang berarti hipotesis kedua diterima dan teruji kebenarannya pada taraf $\alpha=0,05$ sehingga dapat disimpulkan bahwa terdapat korelasi antara motivasi belajar dengan hasil belajar siswa pada kelas eksperimen II. 
Berdasarkan perbandingan nilai ratarata hasil belajar dan nilai rata-rata motivasi belajar siswa pada kelas eksperimen I dan kelas eksperimen II dapat dilihat secara nyata melalui grafik dapat terlihat pada gambar 1 berikut:

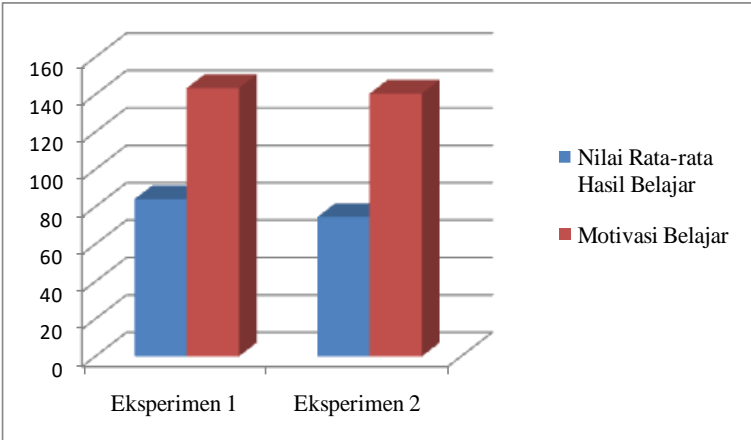

Gambar 1. Diagram nilai rata-rata hasil belajar dan nilai rata-rata motivasi belajar siswa

Berdasarkan gambar 1 diatas dapat disimpulkan bahwa terdapat perbedaan antara nilai rata-rata motivasi belajar siswa dan nilai rata-rata hasil belajar siswa di kelas eksperimen I dan kelas eksperimen II.

Hasil penelitian ini didukung oleh penelitian Anggara (2018), dengan menunjukkan adanya peningkatan hasil belajar siswa menggunakan PBL dengan media Macromedia Flash, dimana diperoleh $t_{\text {hitung }}(4,118)>\mathrm{t}$ tabel $(1.66691)$.

\section{KESIMPULAN}

Berdasarkan hasil analisis data dan pembahasan maka dapat disimpulkan bahwa:

1. Pembelajaran menggunakan model PBL dan DL dengan bantuan macromedia flash bermanfaat untuk meningkatkan nilai hasil belajar siswa, hal tersebut diketahui dari data-data yang diperoleh selama pelaksanaan penelitian di kelas eksperimen I menggunakan model PBL $(84,06)$ dan kelas eksperimen II menggunakan model DL $(74,53)$.

2. Hasil analisis antara motivasi dengan hasil belajar siswa terdapat korelasi yang signifikan, dengan data yang diperoleh selama pelaksanaan penelitian di kelas eksperimen I $(143,50)$ dan di kelas eksperimen II $(140,50)$.
DAFTAR PUSTAKA

Abidin, Y., (2014). Desain Sistem Pembelajaran dalam Konteks Kurikulum 2013, PT Refika aditama, Bandung.

Akhsanul, I., (2017), Learning Geometry Thourgh Discovery Learning Using A Scientific Approach. International Journal of Instruction, 10(1):55-70.

Badaruddin, A., (2015). Peningkatan Motivasi Belajar Siswa Melalui Konseling Klasikal, Kreatifindo, Padang.

Gusbandono, T., Sukardjo, J. S., \& Utomo, S. B., (2013). Pengaruh Metode Pembelajaran Kooperatif Student Team Achievement Division (STAD) Dilengkapi Media Animasi Macromedia Flash dan Plastisin Terhadap Prestasi Belajar Siswa Pada Pokok Bahasan Ikatan Kimia Kelas X Semester 1 SMA Negeri 1 Sambungmacan. Jurnal Pendidikan Kimia, 2(4):102-109.

Ikman, H., \& Monovatra, F. R., (2016). Effect of Problem Based Learning (PBL) Models of Critical Tinking Ability Students On The Eraly Mathematics Ability. International Journal Of Education And Research, 4(7):361-371.

Kurniasih., Imas., \& Salin, B., (2014). Strategi-Strategi Pembelajaran, Alfabeta, Bandung.

Luthfi, I. A., Danial, M., \& Wijaya, M. M., (2016). Perbandingan Metode Pemberian Tugas Kerja Kelompok Dengan Kerja Individu Pada Model Pembelajaran Discovery Learning Terhadap Hasil Belajar Peserta Didik Kelas XI MIA SMAN 1 Tondong Tallasa Kab.Pangkep (Studi Pada Materi Pokok Termokimia). Jurnal Chemica, 17(1):58-66.

Martaida, T., Bukit, N., \& Ginting, E. M., (2017). The Effect of Discovery Learning Model On Student's Critical Thinking Ang Cognitive Ability In Junior High School. Iosr 
Journal of Reseacrh \& Method In Education (Iosr-Jrme), 7(6):1-8.

Sinar., (2018). Metode Active Learning, Budi Utama, Yogyakarta.

Sugiarti., Danial, M., \& Ratnadillah, Y., (2018). Perbandingan Sikap Ilmiah Peserta Didik Yang Menggunakan Model Discovery Learning Dan Pembelajaran Langsung (Studi Pada Materi Pokok Larutan Penyangga). Indonesian Journal of Educational Studies (Ijes), 21(2):98-108.

Suyati., \& Sutiani. A., (2018). Upaya Meningkatkan Hasil Belajar Kimia Siswa Melalui Model Pembelajaran Discovery Learning Pada Materi Termokimia Di MAN 2 Model Medan. Jurnal Penelitian Bidang Pendidikan, 24(1):22-27.

Trianto., (2011). Model Pembelajaran Terpadu Konsep Strategi Dan Implementasinya, Jakarta, Bumi Aksara.

Utami, S. T., Santi, D., \& Suparman, R. A., (2018). Pengaruh Model Pembelajaran Problem Based Learning (PBL) Terhadap Hasil Belajar Kognitif Peserta Didik Kelas XI SMK Negeri 02 Manokwari. Chemistry Education Journal, 1(1):21-26.

Walisda, M. A., Rahman., \& Atmowardoyo, H., (2015). The use of Macromedia Flash Animation to Enhance Student's English Writing Skill At The Seventh Grade of SMP Yapis 1 Fakfak-West Papua. ELT Worldwide, 2(2):46-63.

Widaningsih, I., (2019). Strategi Dan Inovasi Pembelajaran Bahasa Indonesia di Era Revolusi Industry 4.0, Uwais Inspirai Indonesia, Sidoarjo. 